\title{
OPERATING SPEED MODELS OF TWO-LANE RURAL STATE ROADS DEVELOPED ON CONTINUOUS SPEED DATA
}

\author{
Dražen Cvitanić, Biljana Maljković
}

Preliminary communication

This paper presents models for predicting operating speeds on tangent sections and curves of two-lane rural roads developed on continuous speed data. The data corresponds to 20 drivers of different ages and driving experiences, driving their own cars along an $18 \mathrm{~km}$ long section of a state road. The data were first used for determination of minimum operating speeds on curves and maximum operating speeds on tangents and their comparison with speeds in the middle of curves and tangents i.e. speed data used in most of the operating speed studies. There was no significant difference between speed models developed using speed data in the middle of tangents and curves and models developed using maximum and minimum operating speeds on tangents and curves. Models developed on continuous data have higher coefficient of determination than models developed on spot speed data. It can be concluded that the method of measuring has more significant impact on the quality of speed model than the location of measurement.

Keywords: operating speed; continuous speed data; tangent sections; curve; spot speed; consistency

Modeli operativne brzine vangradskih dvotračnih cesta temeljeni na kontinuiranim podacima

Prethodno priopćenje

Ovaj rad prikazuje modele za predviđanje operativne brzine na pravcima i krivinama dvotračnih vangradskih cesta razvijene na kontinuiranim podacima $o$ brzinama vožnje. Podaci se odnose na 20 vozača koji su vozili svoja vozila duž $18 \mathrm{~km}$ duge dionice dvotračne državne ceste. Podaci su prvo korišteni za određivanje minimalne operativne brzine u krivinama i maksimalne operativne brzine na pravcima te njihovu usporedbu s brzinama, u sredini krivina $i$ pravaca, koje se najčešće koriste za razvoj modela operativnih brzina. Nema značajne razlike između modela brzina razvijenih na temelju podataka o brzinama na sredini pravaca i krivina i modela razvijenih na temelju podataka o maksimalnim i minimalnim operativnim brzinama na pravcima, odnosno krivinama. Modeli razvijeni na temelju kontinuiranih podataka imaju veći koeficijent determinacije od modela razvijenih na temelju točkastih podataka o brzinama u sredini pravaca i krivina. Stoga se može zaključiti da metoda mjerenja ima značajniji utjecaj na kvalitetu modela brzina od mjesta mjerenja.

Ključne riječi: operativne brzine; kontinuirani podaci o brzinama; pravac; krivina; brzina u presjeku; konzistencija

\section{Introduction}

Examining the accident reports many researches have concluded that one of the main causes of accident occurrence is the lack of geometric design consistency in

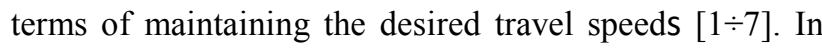
order to improve safety, a number of road safety programs have been established, and among the most promising strategies is the implementation of the concept of design consistency [8]. Design consistency refers to the ability of geometric characteristics of the road to conform to driver's expectations [9]. A consistent road design ensures coordinated successive elements producing harmonized driver behaviour with no surprising events. Among the different existing measures for design consistency evaluation, the operating speed approach can be named as the most efficient and quantified measure [10]. Therefore, the first step in evaluating road design consistency is a development of statistical model that can predict operating speeds based on the geometric characteristics of the alignments elements.

In the past sixty years many operating speed studies around the world have been conducted [11]. The traditional approach is to predict operating speeds separately on curves and tangent sections. Just a few authors developed continuous operating speed model on successive elements of highway alignment $[12,13]$.

Majority of studies resulted in operating speed models on horizontal curves while there have been only a few attempts to develop speed models on tangents. There are a few reasons for the lack of modelling speed on tangent sections. Horizontal curves are high-accident locations, so the curve speed is the principal parameter for safety evaluation. Also, it is easier to model the operating speed on curves because of the strong correlation with the curvature of the alignment element [13]. On the other hand, there is an opinion that the tangent speed depends on too many parameters [14], so it is hard to establish a reliable model.

Operating speeds on curves show significant dependence only on a few parameters of which the most important is radius or curvature of the alignment element. The coefficient of determination $R^{2}$ of these models is usually greater than 0.7 . Including the approach tangent speed as an independent variable, $R^{2}$ increases to more than 0.85 [15].

The results of speed models on tangent sections are not so good. In the analysis of 162 tangent sections on two lane rural highways [14] it was not possible to develop a model capable to describe the operating speed in the middle of tangent section because of its dependency on the elements before and after the section. So, researchers separated the tangents in four groups according to tangent length and sharpness of the preceding and the following curve. The corresponding coefficients of determination ranged from 0.55 to 0.84 . Federal Highway Administration (FHWA) developed speed profile models for lower speed highways (up to 64 $\mathrm{km} / \mathrm{h}$ ) for use in Interactive Highway Safety Design Model ISHDM 2010 release. Separate models were developed for short $(<45 \mathrm{~m})$ and long tangents. Resulting $R^{2}$ were pretty low. Coefficient of determination for short tangents model was 0.49 (the predicting variables were posted speed and radius of the curve). For longer tangents the posted speed, roadside hazard and length of tangent were found to impact the operating speed. Coefficient of 
determination of this model was 0.29. Ottesen and Krammes [16] developed operating speed model in curves with the approach tangent speed as an independent variable. Because it was not possible to develop an appropriate model for long tangents, a constant value of $97.7 \mathrm{~km} / \mathrm{h}$ was considered as the desired speed on long tangents.

Better results were achieved by using environmental speed as a reference value for both short (dependent) and long (independent) tangents [17]. Authors proposed a new operating speed model in which the geometric features of the previous and oncoming alignment were explicitly considered.

The main purpose of the operating speed model is evaluation of design consistency. Design consistency for a single road element can be assessed by comparing the operating and design speed and also by determining the margin of safety i.e. the difference between side friction supply and side friction demand [18]. Operating speed differential between curve and tangent section is used to evaluate the consistency in the transition between two successive geometric elements. It is therefore very important to develop methodologies suitable for estimating the speed behaviour of drivers not only on curves but also on tangent sections.

Although numerous studies have been developed in order to determine operating speeds, most of them were based on spot speeds and certain assumptions about drivers' behaviour. The lowest speeds along the horizontal curves and highest speeds along tangents are considered to be the desired drivers' speeds. The researchers collected speed data at specific locations of a roadway, mostly at the middle point of horizontal curves and tangents, or $200 \mathrm{~m}$ before the end of tangents [19] using a radar gun or a similar device. Due to the lack of data, many models used the assumption of a constant speed along the horizontal curve. These assumptions may not be realistic [20]. Except for the unrealistic assumptions of driver behaviour, there are also some other disadvantages of spot speed data measuring like cosine error, drivers changing their behaviour in the presence of test equipment, and human error when reading data from the device display [10].

Because of many shortcomings of spot speed measurement and with the development of technology, more and more researchers focus on continuous speed data. In the past decade, several operating speed studies have been conducted based on continuous measured data using a GPS device $[13,20]$.

The main purpose of this paper is to analyze whether mentioned shortcomings of spot speed measurement and the assumptions of previous operating speed studies like achieving minimum speeds in the middle of the curves and maximum speeds in the middle of tangent sections have impact on the quality of operating speed models.

\section{Data collection}

Test rides with vehicles equipped with a $10 \mathrm{~Hz}$ GPS data logger, which measures speed, position, curvature, acceleration and heading, were carried on a $20 \mathrm{~km}$ long road segment. The analyzed road segment is a two-lane rural state road with a relatively low traffic volume (the average annual daily traffic is about $1400 \mathrm{veh} /$ day) and no intersections with major roads. The test rides were recorded during the day under optimal weather and free flow conditions, i.e. the headway between the test vehicle and the preceding or the following vehicle was greater than 5 seconds, in order to reduce the conditions not related to the geometry of the alignment $[15,19,21]$.

Geometric characteristics of the road segment were obtained from the main road design and were verified using detailed geodetic as-built alignment data. Operating speed prediction models were developed based on the speed data from an $18 \mathrm{~km}$ long road segment, and the model validation was made with the data from a $2 \mathrm{~km}$ long segment of the road. The analyzed $18 \mathrm{~km}$ long section consists of 64 horizontal curves with radii varying from 85 to $1010 \mathrm{~m}$ and 64 tangents with lengths varying from 10 to $683 \mathrm{~m}$. Geometric characteristics of the analyzed road segment are presented in Tab. 1 .

Table 1 Geometric characteristics of the analyzed road segment

\begin{tabular}{|c|l|c|c|c|c|}
\hline \multirow{2}{*}{ Element } & \multicolumn{1}{|c|}{$\begin{array}{c}\text { Geometric } \\
\text { characteristics }\end{array}$} & Min & Max & Mean & St. Dev. \\
\hline \multirow{3}{*}{ Curve } & Radius (m) & 85 & 1010 & 300 & 229 \\
\cline { 2 - 6 } & Length (m) & 40 & 440 & 147 & 99 \\
\cline { 2 - 6 } & Deflection $\left({ }^{\circ}\right)$ & 4 & 118 & 41 & 28 \\
\cline { 2 - 6 } & Elevation (\%) & 2 & 7 & 3.4 & 1.4 \\
\hline Tangent & Length (m) & 0 & 683 & 101 & 110 \\
\hline Spiral & Length (m) & 0 & 60 & 32 & 10 \\
\hline Hor. Alignment & Grade (\%) & 0.5 & 6 & 2.1 & 1.5 \\
\hline
\end{tabular}

The test driver sample consisted of 20 people with ages ranging from 23 to 60 years and with different driving experiences (from 5 to more than 30 years). The test vehicles were personal cars of different types and ages.

The value and location of the minimum speed on curve and the maximum speed on tangent were determined from each ride's continuous speed profile. Also, the speeds in the middle of curves and tangent section as well as the speeds $200 \mathrm{~m}$ before the end of long tangents were recorded.

The values of operating speeds $V_{85}$ determined from the continuous speed data collected on the $18 \mathrm{~km}$ long road segment were used for analyzing the locations and values of speeds on curves and tangents relevant to the development of operating speed models. After defining the relevant speeds, the operating speed prediction models for tangent sections were developed based on the geometric characteristics of the road. Additionally, using the predicted speeds on tangents, the operating speed models for horizontal curves were developed.

\section{Analysis of data}

In order to investigate the assumptions of previous operating speed studies, the minimum operating speeds on curves and the operating speeds in the middle of curves were compared, as well as the maximum operating speeds on tangents and the speeds in the middle of tangents. The locations of minimum curve speed and maximum tangent speed were also analyzed. 


\subsection{Speeds on curves}

Table 2 Speed data on curves

\begin{tabular}{|c|c|c|c|c|c|c|c|}
\hline $\begin{array}{l}\text { Curve } \\
\text { No. }\end{array}$ & $\begin{array}{c}R \\
(\mathrm{~m})\end{array}$ & $\begin{array}{l}T_{\text {bef }} \\
(\mathrm{m})\end{array}$ & $\begin{array}{l}T_{\text {aft }} \\
(\mathrm{m})\end{array}$ & $\begin{array}{l}V_{85 \text { min }} \\
(\mathrm{km} / \mathrm{h})\end{array}$ & $\begin{array}{l}V_{85 \text { midle }} \\
(\mathrm{km} / \mathrm{h})\end{array}$ & $\begin{array}{c}\text { Delta } \\
V_{85}(\%)\end{array}$ & Loc. \\
\hline R1 & 155 & 100 & 52 & 71,9 & 72,8 & 1 & 1 \\
\hline $\mathrm{R} 2$ & 150 & 52 & 55 & 70,5 & 72,9 & 3 & 2 \\
\hline R3 & 140 & 55 & 58 & 71,1 & 72,7 & 2 & 1 \\
\hline R4 & 125 & 58 & 23 & 67,8 & 69,3 & 2 & 1 \\
\hline $\mathrm{R} 5$ & 110 & 23 & 68 & 69,0 & 72,3 & 5 & 1 \\
\hline R6 & 800 & 68 & 136 & 89,7 & 95,2 & 6 & 1 \\
\hline R7 & 100 & 136 & 41 & 70,4 & 71,5 & 2 & 3 \\
\hline R8 & 100 & 41 & 33 & 65,2 & 67,5 & 3 & 1 \\
\hline R9 & 105 & 33 & 29 & 69,9 & 71,4 & 2 & 2 \\
\hline R10 & 100 & 29 & 46 & 65,9 & 68,2 & 3 & 1 \\
\hline R11 & 120 & 46 & 31 & 68,2 & 68,7 & 1 & 2 \\
\hline R12 & 350 & 31 & 22 & 77,4 & 79,4 & 3 & 1 \\
\hline R13 & 310 & 22 & 10 & 78,7 & 80,2 & 2 & 3 \\
\hline R14 & 150 & 10 & 10 & 73,2 & 75,1 & 2 & 3 \\
\hline R15 & 110 & 10 & 10 & 68,8 & 69,0 & 0 & 1 \\
\hline R16 & 170 & 10 & 83 & 72,7 & 74,7 & 3 & 1 \\
\hline R17 & 350 & 83 & 340 & 78,3 & 79,3 & 1 & 1 \\
\hline R18 & 240 & 340 & 124 & 81,5 & 82,0 & 1 & 1 \\
\hline R19 & 105 & 124 & 30 & 65,6 & 66,5 & 1 & 1 \\
\hline R20 & 160 & 30 & 72 & 67,1 & 69,6 & 4 & 1 \\
\hline R21 & 180 & 72 & 42 & 75,5 & 76,5 & 1 & 1 \\
\hline R22 & 175 & 42 & 10 & 75,9 & 77,5 & 2 & 1 \\
\hline R23 & 270 & 10 & 43 & 76,7 & 78,8 & 3 & 1 \\
\hline R24 & 85 & 43 & 10 & 68,2 & 68,4 & 0 & 2 \\
\hline R25 & 200 & 10 & 133 & 73,1 & 74,8 & 2 & 1 \\
\hline R26 & 80 & 133 & 20 & 64,4 & 65,4 & 2 & 3 \\
\hline R27 & 105 & 20 & 72 & 61,7 & 63,2 & 3 & 1 \\
\hline R28 & 125 & 72 & 23 & 67,9 & 68,6 & 1 & 1 \\
\hline R29 & 470 & 23 & 153 & 75,5 & 77,8 & 3 & 1 \\
\hline R30 & 850 & 153 & 78 & 85,6 & 87,0 & 2 & 1 \\
\hline R31 & 260 & 78 & 201 & 86,8 & 88,6 & 2 & 1 \\
\hline R32 & 600 & 201 & 0 & 85,6 & 88,3 & 3 & 1 \\
\hline R33 & 300 & 0 & 48 & 83,4 & 84,9 & 2 & 3 \\
\hline R34 & 120 & 48 & 89 & 72,2 & 73,4 & 2 & 1 \\
\hline R35 & 200 & 89 & 30 & 79,1 & 81,5 & 3 & 1 \\
\hline R36 & 100 & 30 & 42 & 69,5 & 70,6 & 2 & 1 \\
\hline R37 & 200 & 42 & 33 & 74,6 & 77,1 & 3 & 1 \\
\hline R38 & 175 & 33 & 77 & 80,8 & 81,8 & 1 & 1 \\
\hline R39 & 400 & 77 & 32 & 83,7 & 86,1 & 3 & 1 \\
\hline $\mathrm{R} 40$ & 245 & 32 & 52 & 83,4 & 84,3 & 1 & 3 \\
\hline R41 & 180 & 52 & 65 & 80,3 & 81,0 & 1 & 1 \\
\hline R42 & 250 & 65 & 167 & 84,7 & 86,6 & 2 & 1 \\
\hline R43 & 1010 & 167 & 123 & 93,4 & 95,4 & 2 & 1 \\
\hline R44 & 610 & 123 & 683 & 93,9 & 96,4 & 3 & 1 \\
\hline R45 & 350 & 683 & 40 & 92,8 & 93,9 & 1 & 1 \\
\hline R46 & 840 & 40 & 230 & 93,7 & 96,2 & 3 & 1 \\
\hline R47 & 320 & 230 & 130 & 83,4 & 84,1 & 1 & 1 \\
\hline R48 & 150 & 130 & 60 & 73,5 & 74,7 & 2 & 1 \\
\hline R49 & 180 & 60 & 30 & 77,2 & 81,0 & 5 & 3 \\
\hline R50 & 150 & 30 & 75 & 72,5 & 73,0 & 1 & 2 \\
\hline R51 & 360 & 75 & 100 & 77,9 & 81,8 & 5 & 1 \\
\hline R52 & 890 & 100 & 370 & 93,2 & 94,2 & 1 & 1 \\
\hline R53 & 605 & 370 & 135 & 91,7 & 94,9 & 3 & 3 \\
\hline R54 & 350 & 135 & 470 & 85,1 & 88,6 & 4 & 3 \\
\hline R55 & 310 & 470 & 90 & 85,4 & 88,1 & 3 & 1 \\
\hline R56 & 250 & 90 & 20 & 82,5 & 83,3 & 1 & 2 \\
\hline R57 & 200 & 20 & 190 & 80,9 & 82,1 & 2 & 1 \\
\hline R58 & 510 & 190 & 55 & 91,2 & 92,3 & 1 & 3 \\
\hline R59 & 310 & 55 & 210 & 85,8 & 86,2 & 0 & 1 \\
\hline R60 & 900 & 210 & 220 & 89,4 & 89,2 & 0 & 2 \\
\hline R61 & 530 & 220 & 80 & 86,0 & 87,6 & 2 & 3 \\
\hline R62 & 350 & 80 & 205 & 82,9 & 90,1 & 9 & 1 \\
\hline R63 & 410 & 205 & 145 & 81,6 & 85,4 & 5 & 1 \\
\hline R64 & 145 & 145 & 175 & 77,1 & 77,7 & 1 & 2 \\
\hline
\end{tabular}

Tab. 2 presents the locations and values of the minimum operating speeds on curves $\left(V_{85} \mathrm{~min}\right)$, the operating speeds in the middle of the curve $\left(V_{85}\right.$ middle $)$ and the geometric characteristics of road alignment elements: curve radius $(R)$, tangent length before and after the curve ( $T_{\text {bef }}$ and $T_{\text {aft }}$ ). Location 1 means that the maximum speed was achieved in the first part of the curve length, location 2 in the second part and location 3 in the third part of the curve length.

The average difference between the minimum operating speeds $V_{85}$ min and the operating speeds in the middle of the curve $V_{85}$ middle is $2 \%$ and the maximum difference is $6 \%$.

The locations of the minimum individual driver's speed, as well as the locations of the operating speeds are dispersed all over the curve length. For majority of curves (70\%), the minimum operating speeds are located in the first third of the curve length.

The analysis of individual drivers' speed profiles indicated two reasons why the minimum operating speeds were mostly located in the first third of the curve length. On the sharper curves $(R<200 \mathrm{~m})$ drivers begin to slow down on tangent before the curve and continue to decelerate in the first part of the curve to the desired comfortable speed after which they start to accelerate in accordance to curvature and length of the next element (for example curves: R1, R3, R4, R5). In the mild curves $(R>300 \mathrm{~m})$ following short tangents drivers did not reach the desired travel speed on tangent section so they still accelerate to the desired speed on the curve, resulting in the minimum speeds being located in the first part of the curve length (for example curves: R6, R12, R17, R29).

The minimum operating speeds are located in the last section of curve length for two cases. The first case is the one in which the preceding element is a long tangent or a curve with significantly greater radius than the subject curve, so that drivers are decelerating all over the curve length (R7, R14, R26, R54, R61) resulting in the minimum speeds in second or third part of curve length. The second case is the one in which the subject curve radius is significantly greater than the following curve radius, so that drivers decelerate from the middle to the end of the curve to adopt a speed comfortable for the next curve radius (R13, R33, R49, R58).

\subsection{Speeds on tangent sections}

On short tangents the maximum speeds are dispersed all over tangent length, depending on the preceding and the following curve radius, as well as on the driving style of each driver. It was not possible to find a general rule for the location of the maximum free flow speeds.

On long tangents $(>150 \mathrm{~m})$ most of the maximum operating speeds are located in the middle of the tangent. Tab. 3 presents the data about tangent length $(T)$, the radius of curve before and the radius of curve after the tangent $\left(R_{\text {bef }}\right.$ and $R_{\text {aft }}$ ), the location of the maximum operating speed, the maximum operating speed $\left(V_{85}\right.$ max $)$, the operating speed $200 \mathrm{~m}$ before the end of the tangent $\left(V_{85} 200\right)$ and the operating speed in the middle of the tangent ( $V_{85}$ middle $)$ for some of the long tangents. Location 1 represents the maximum speed achieved in the first part of the tangent length, location 2 is for the second part and location 3 is for the third part of the tangent. The maximum difference between $V_{85 \_ \text {middle }}$ and $V_{85 \_ \text {max }}$ is $4 \%$. 
The maximum difference between $V_{85}$ middle and $V_{85 \_200}$ is $2 \%$.

Table 3 Speed data on long tangents

\begin{tabular}{|c|c|c|c|c|c|c|c|}
\hline $\begin{array}{c}\text { Tangent } \\
\text { No. }\end{array}$ & $\begin{array}{c}T \\
(\mathrm{~m})\end{array}$ & $\begin{array}{c}R_{\text {bef }} \\
(\mathrm{m})\end{array}$ & $\begin{array}{c}R_{\mathrm{aft}} \\
(\mathrm{m})\end{array}$ & Loc. & $\begin{array}{c}V_{85 \_m a x} \\
(\mathrm{~km} / \mathrm{h})\end{array}$ & $\begin{array}{c}V_{85 \_200} \\
(\mathrm{~km} / \mathrm{h})\end{array}$ & $\begin{array}{c}V_{85 \_ \text {middle }} \\
(\mathrm{km} / \mathrm{h})\end{array}$ \\
\hline $\mathrm{T} 18$ & 336 & 350 & 250 & 2 & 87,8 & 86,6 & 97,7 \\
\hline $\mathrm{T} 41$ & 683 & 610 & 350 & 3 & 106,0 & 102,0 & 115,4 \\
\hline $\mathrm{T} 43$ & 230 & 840 & 320 & 1 & 98,4 & 97,9 & 109,1 \\
\hline $\mathrm{T} 49$ & 370 & 900 & 600 & 2 & 99,3 & 97,8 & 109,0 \\
\hline T51 & 470 & 350 & 310 & 2 & 94,9 & 92,4 & 104,8 \\
\hline
\end{tabular}

The continuous data collected in this study showed that the assumptions that drivers reach their highest speeds in the middle of tangents, or $200 \mathrm{~m}$ before the end of tangent, and reach their lowest speeds in the middle of horizontal curves, are not realistic, in general. However, the differences are not significant. The average difference is $2 \%$, the maximum difference is $6 \%$ on curves and $4 \%$ on long tangents. Furthermore, it was found that the standard deviation is about $5 \mathrm{~km} / \mathrm{h}$ on sharp curves, $8 \mathrm{~km}$ on mild curves, while on the tangent sections longer than $200 \mathrm{~m}$ and the curves with radius $R>350 \mathrm{~m}$, it increases up to $10 \mathrm{~km} / \mathrm{h}$. This makes sense, because in sharp curves all drivers are forced to slow down, while on long tangents they can choose their desired speed according to their characteristics.

Based on the results of data analysis, it can be assumed that the disparity of locations and values of the minimum and maximum speeds and other spot speed data measurements shortcomings could be a reason for low correlation between the operating speed on tangents and the geometric characteristics of the road for the models developed on spot speed data. Therefore, in this study, operating speed models for the maximum values of speed on tangents and the minimum values of speed in curves, as well as for the speeds in the middle of the curves and tangents were developed and compared.

\section{Operating speed models \\ 4.1 Operating speed models on tangents}

Operating speeds models for tangent sections are developed based on two sets of data. The first data set represents the maximum operating speeds on tangent sections, and the second set represents operating speeds in the middle of the tangents.

Operating speed models on tangent sections usually use linear regression, including variety of geometric characteristics of the alignment [14]. The independent variables chosen for the analysis in this study are tangent length $(T)$, radius of the previous and following curve ( $R_{\mathrm{bef}}$ and $R_{\mathrm{aft}}$ ), deflection angle of the previous and following curve, length of the previous and following curve, length of the previous and following spirals and grade.

Stepwise multiple linear regression indicated tangent length $T$, radius of the previous curve $R_{\text {bef }}$ and radius of the following curve $R_{\mathrm{aft}}$ as statistically significant independent variables. Other variables did not have significant impact on the coefficient of determination. Several models were examined and the best fit model for predicting the maximum operating speeds on tangent section was:

$$
\hat{V}_{85}^{T}=13+6,92 \cdot \ln R_{\mathrm{bef}}+3,69 \cdot \ln R_{\mathrm{aft}}+2,97 \cdot \ln T
$$

The model shows a high coefficient of determination $R^{2}=0.85$ as well as an adjusted coefficient of determination $R_{\text {adj }}^{2}=0.85$. In addition each coefficient has a high $t$-statistic with $p$ value less than 0.0001 , indicating the significant contribution of both variables to the model. Logarithmic function is used because it can describe the dependence between speed and tangent length or curve radius better than a linear function. Namely, increasing the length of a short tangent or increasing the radius of a sharp curve results in significant increase in speed. Increasing the length of long tangents, or increasing the radius of mild curves results in minor increase of speed, and this is described well by the logarithmic function. The quality of the model is further evaluated using mean absolute percentage error (MAPE) defined as:

$M A P E=\sum_{i}\left|\frac{\hat{V}_{85}^{T}-V_{85}^{T}}{V_{85}^{T}}\right|$

The overall MAPE for the data from the $18 \mathrm{~km}$ long segment is $3.1 \%$ and the maximum individual absolute percentage error $(A P E)$ is $11.5 \%$.

Validation of the model is performed on the $2 \mathrm{~km}$ long test section outside the section used for model development. The MAPE of the model is $1.9 \%$ and the maximum individual $A P E$ is $4.1 \%$.

The second set of data, i.e., the operating speeds in the middle of tangent, resulted in slightly different model parameters, but with same $R^{2}$ and $M A P E$ as the described model. It indicates that it does not make much of a difference which recorded data is used for the development of tangent speed model.

The obtained results of models are very good, especially in comparison with the models developed on spot speed data measured by a laser gun. Thus, it can be concluded that the method of measurement has a more significant impact on the quality of tangent speed prediction than the location of measurement. That is, the spot speed data collected by a radar gun or a similar device could be biased by the cosine error, drivers changing their behaviour in the presence of test equipment and the human error when reading data from the device display. Therefore, the continuous speed profile of drivers of different sex, age and experience driving their own cars represents the most reliable basis for developing tangent speed models. On the other hand, the continuous speed measurement is harder to carry out because of the need for a high number of test drivers which have to be properly chosen in order to represent the entire population in the sense of sex, age, driving experience and vehicle types. In this study, the number of test drivers was not enough for the development of a statistically robust model. Nevertheless, the study shows that continuous speed data can be used to develop a reliable model for prediction of operating speeds on tangents sections of various lengths, from short tangents 
in which vehicles face insufficient length to reach high speeds (so called non-independent tangents), to long independent tangents which permit vehicles to accelerate up to free-flow operating speeds.

\subsection{Operating speed models on horizontal curves}

The majority of the existing operating speed models on horizontal curves were made using linear regression with variety of geometric and traffic characteristics of the alignment. All of these models include the effect of curvature on speed. Several other models also include approach speed as an independent variable, which has a significant impact on the curve speed prediction model coefficient of determination [15].

To determine the appropriate horizontal curve speed model based on the data collected on the $18 \mathrm{~km}$ long segment of the state road authors used a stepwise multiple regression procedure. Data from 64 horizontal curves $(80$ $\mathrm{m}<R<1010 \mathrm{~m}$ ) were used for model determination and speed data from 9 curves $(95 \mathrm{~m}<R<420 \mathrm{~m})$ on the $2 \mathrm{~km}$ long section were used for model validation.

The tangent speed model indicated that the speeds on tangents depend not only on the preceding curve radius but also on the following curve radius. Analogously, it is likely that the minimum operating speed on curve depends not only on the approach speed but also on the departure speed especially for the curves on which the minimum speeds were located in the last part of the curve length. Thus, in this study were analyzed the following independent variables: curve radius, deflection angle, grade, superelevation, length of curve, approach and departure speed. A stepwise regression indicated that beside curve radius and measured approach speed, only departure speed has a significant impact on curve speed.

The model which includes approach and departure speed resulted in a high adjusted coefficient of determination $R_{\text {adj }}^{2}=0.95$. The model which includes just approach speed resulted in coefficient of determination $R_{\text {adj }}^{2}=0.9$.

There is one practical problem in estimation of curve speed from this model, i.e. one needs to know approach and departure tangent speed. As it is impractical to measure speed data for all the existing roads and it is impossible to get data for planned roads, in this study estimated tangent speed from model (1) was used as an independent variable.

Although it has been shown that measured departure speed has impact on the minimum operating speed on curve, the conducted stepwise regression indicated that estimated departure speed has no significant impact on curve speed so it is excluded from the model. Several models with radius of curve and approach speed as significant independent variables were examined and the best fit model is:

$$
\hat{V}_{85}^{C}=2,9+8,23 \cdot \ln R+0,364 \cdot \hat{V}_{85}^{T}
$$

with natural logarithm of horizontal curve radius $(R)$ and estimated approach tangent speed $\left(\hat{V}_{85}^{T}\right)$ as independent variables. The coefficient of determination of the model is equal to 0.86 while the adjusted coefficient of determination is equal to 0.85 , a reasonably good result.
Using estimated tangent speed instead of measured tangent speed resulted in a minor decrease of the adjusted coefficient of determination $(0.05$ or $6 \%)$. When using a model without approach speed as an independent variable, the adjusted coefficient of determination decreased to 0.8 . The accuracy of the model was also expressed by the $M A P E$. The overall MAPE for the data from the $18 \mathrm{~km}$ long segment is $3.3 \%$ and the maximum $A P E$ is $8.7 \%$. The model validation was made with the data from the 2 $\mathrm{km}$ long section of the road. The overall MAPE is $3.6 \%$ and the maximum $A P E$ is $8 \%$.

As for the tangents, a curve speed model was developed for the speeds measured in the middle of the curve, too. The resulting model has slightly different coefficients and the same adjusted coefficient of determination. It confirms the assumption that the measurement method has a more significant impact on model quality than the location of speed measurement.

\section{Analysis of results for speed models on tangent and curves}

Fig. 1 and Fig. 2 present the overall results of the developed speed models. Fig. 1 presents the estimated and measured operating speeds on tangents and curves for the analyzed road sections (model development and validation section). Fig. 2 presents the absolute percentage errors between the measured and estimated speeds on the analyzed sections. Analyzing overall results of both speed models it was found that the maximum APE is $11.5 \%$ for model development data while the maximum $A P E$ for model validation data is $8 \%$. MAPE for model development data is $3.2 \%$ and $M A P E$ for validation data is $2.7 \%$. The $A P E$ and $M A P E$ values for validation data are even lower than the values for model development data, which means that the models predict accurately the curve and tangent speed choice of the driving population. Thus, it can be concluded that the approach used in this paper resulted in a reliable model for prediction of speeds on all relevant elements of horizontal alignment. These speeds can be used for drawing a continuous speed profile and evaluation of road design consistency.

\section{Conclusion}

This paper presents operating speed models on tangent sections and horizontal curves based on the collected continuous speed data measured by a $10 \mathrm{~Hz}$ GPS device. Unlike spot speed methodologies, continuous speed data allows determination of the locations and unbiased values of the relevant operating speeds on tangents and horizontal curves. Most previous speed models were based on the assumption that drivers reach their highest speeds in the middle of tangents and reach their lowest speeds in the middle of horizontal curves. The continuous data collected in this study showed that these assumptions are not realistic, in general. The speed throughout a curve does not remain constant and the locations of the lowest speeds on curves and highest speeds on tangents differ from driver to driver and depend on the geometric characteristics of the preceding and the following elements of horizontal alignment. 


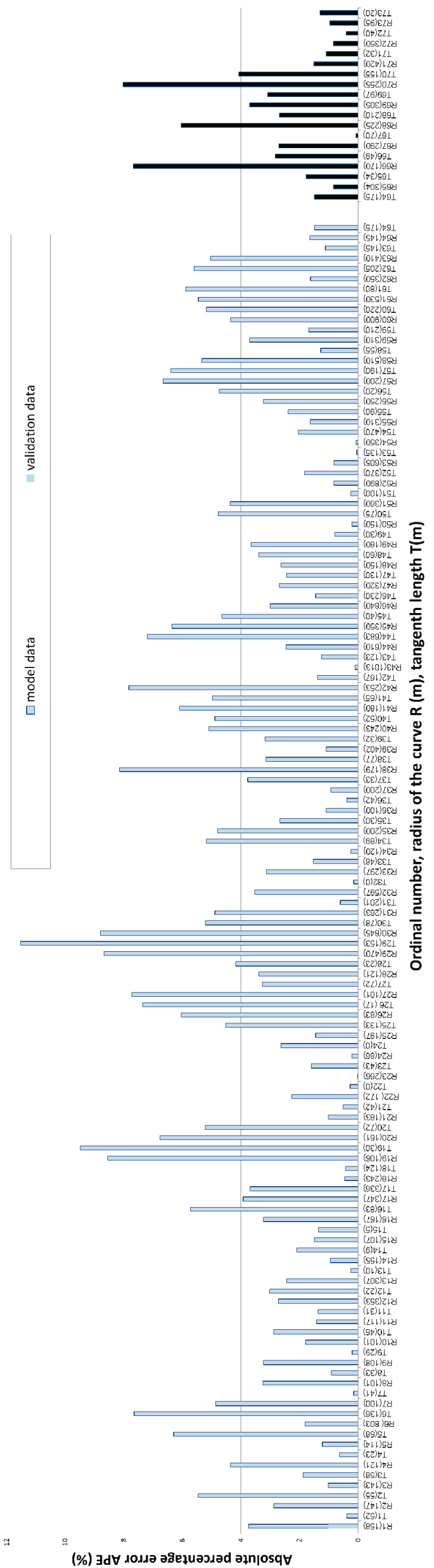

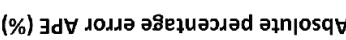

Figure 1 Meausured and estimated speeds for model development and validation data

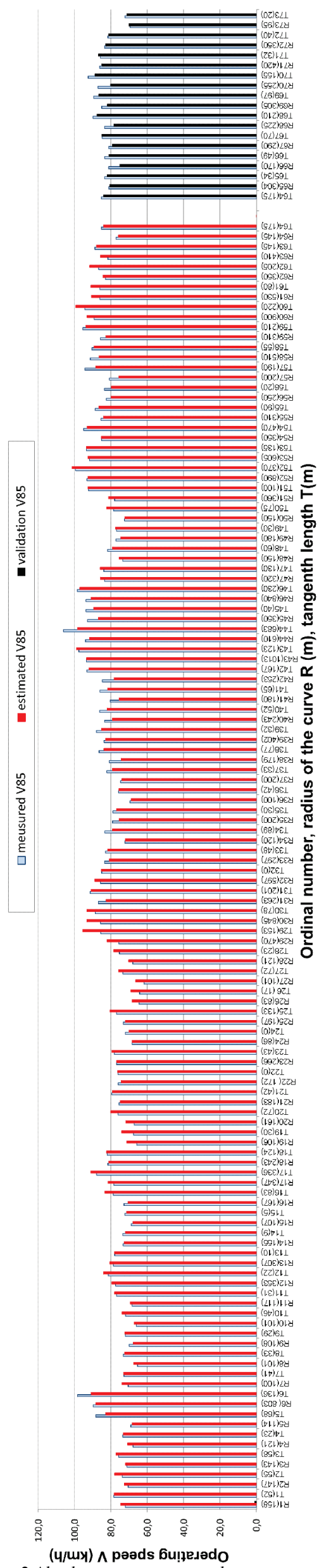

Figure 2 Absolute percentage error between meausured and estimated speeds 
However, the developed speed models showed that there is no significant difference in model parameters and coefficients of determination when the maximum and the minimum speeds on tangents and curves were used, or when the speeds in the middle of curves and tangents were used. Thus, it can be concluded that the method of measurement has a more significant impact on the quality of the tangent speed prediction than the location of measurement. That is, the spot speeds measured by a radar gun or a similar device have shortcomings such as the cosine error, drivers changing their behaviour in the presence of test equipment and human error when reading data from the device display, none of which is the case with the data from the continuous speed profile.

A continuous speed data were first used for development of tangent speed model. Then a curve speed model is developed using the predicted speed on tangents as one of the independent variables. The developed operating speed models on tangents and horizontal curves resulted in a high level of reliability. $M A P E$ on the validation data of $2.7 \%$ and $A P E$ of only $8 \%$ are even lower than $M A P E$ and $A P E$ for the model development data.

The advantage of the developed tangent speed model in comparison with other developed models is in that it can predict speeds on short and long tangents very reliably and these speeds can then be used as the values of the independent variable in the curve speed model. These speeds can be used for evaluation of road design consistency. Another advantage is in that the developed models are based on the continuous speeds measured under true driving conditions for drivers of different age, aggressiveness and driving experience, driving their own cars of different type and age.

\section{References}

[1] Abdel-Aty, M. A.; Radwan, A. E. Modeling traffic accident occurrence and involvement. // Accident Analysis \& Prevention 32, 5(2000), pp. 633-642. https://doi.org/10.1016/S0001-4575(99)00094-9

[2] Hassan, Y. Highway Design Consistency - Refining the State of Knowledge and Practice. // Transportation Research Record 1881, (2004), pp. 63-71. https://doi.org/10.3141/1881-08

[3] Polus, A.; Matter-Habib, C. New Consistency Model for Rural Highways and Its Relationship to Safety. // J. Transp. Eng., 130, 3(2004) pp. 286-293. https://doi.org/10.1061/(ASCE)0733-947X(2004)130:3(286)

[4] Ikeda, T.; Mori, N. Analysis of correlation between roadway alignment and traffic accidents. // Third International Symposium on Highway Geometric Design, TRB's Conference Recording series, 2005, pp. 69-88.

[5] Haynes, R.; Lake, I.; Kinghamb, S.; Sabel, C.; Pearce, J.; Barnett, R. The influence of road curvature on fatal crashes in New Zealand. // Accident Analysis and Prevention, 40, 3, (2008), pp. 843-850. https://doi.org/10.1016/j.aap.2007.09.013

[6] Cafiso, S.; Di Graziano, A.; Di Silvestro, G.; La Cava, G.; Persaud, B. Development of comprehensive accident models for two-lane rural highways using exposure, geometry, consistency and context variables. // Accident Analysis \& Prevention, 42, 4(2010), pp. 1072-1079. https://doi.org/10.1016/j.aap.2009.12.015

[7] De Luca, M.; Dell'Acqua, G. Freeway Safety Management: Case Studies in Italy. // Transport 27, 3(2012), pp. 320-326. https://doi.org/10.3846/16484142.2012.724447
[8] Hassan, Y; Sayed, T.; Tabernero, V. Establishing practical approach for design consistency evaluation. // J. Transp. Eng., 127, 4(2001), pp. 295-302. https://doi.org/10.1061/(ASCE)0733-947X(2001)127:4(295)

[9] Nicholson, A. Superelevation, side friction and roadway consistency. // J. Transp. Eng. 124, 5(1998), pp 411-418. https://doi.org/10.1061/(ASCE)0733-947X(1998)124:5(411)

[10] Misaghi, P.; Hassan, Y. Modeling operating speed and speed differential on two lane rural roads. // J. of Transp. Eng., 131, 6(2005), pp. 408-418. https://doi.org/10.1061/((ASCE)0733-947X(2005)131:6(408)

[11] Modelling Operating Speed: Synthesis Report. Transportation Research Circular number E-C151, Transportation Research Board (2011).

[12] Dell'Acqua, G.; Russo, F. Speed Factors on Low-Volume Roads for Horizontal Curves and Tangents. // Baltic Journal of Road and Bridge Engineering. 5, 2(2010), pp. 89-97. https://doi.org/10.3846/bjrbe.2010.13

[13] Cafiso, S.; Cerni, G. New approach to defining continuous speed profile models for two-lane rural roads. // Transportation Research Record 2309, pp. 157-167. https://doi.org/10.3141/2309-16

[14] Polus, A.; Fitzpatrick, K.; Fambro, D. B. Predicting operating speed on tangent sections of two lane rural highways. // Transportation Research Record 1737, (2000), pp. 50-57. https://doi.org/10.3141/1737-07

[15] Bonneson, J. A. Side Friction and Speed as Controls for Horizontal Curve Design. // J. Transp. Eng., 125, 6(1999), pp. 473-480. https://doi.org/10.1061/(ASCE)0733-947X(1999)125:6(473)

[16] Ottesen, J.; Krammes, R. A. Speed-Profile Model for a Design Consistency Evaluation Procedure in the United States. // Transportation Research Record 1701, (2000), pp. 76-85. https://doi.org/10.3141/1701-10

[17] Praticò, F. G.; Giunta, M. Quantifying the effect of present, past and oncoming alignment on the operating speeds of a two-lane rural road. // The Baltic Journal of Road and Bridge Engineering. 7, 3(2012), pp. 181-190. https://doi.org/10.3846/bjrbe.2012.25

[18] Lamm R. et al. A Practical Safety Approach to Highway Geometric Design International Case Studies: Germany, Greece, Lebanon, and the United States.// International Symposium on Highway Geometric Design Practices. Transportation Research Circular. Transportation Research Board, Boston, Massachusetts, 1995, pp. 9-14.

[19] Fitzpatrick, K. et al. Design Speed, Operating Speed, and Posted Speed Practices. NCHRP, report 504, 2003.

[20] Wang, J. Operating Speed Models for Low Speed Urban Environments Based on In-Vehicle GPS Data. // Dissertation, Georgia Institute of Technology, 2006, 183 p.

[21] Said, D.; Hassan, Y.; Abd El Halim, A. O. Comfort thresholds for horizontal curve design. // Canadian Journal of Civil Engineering, 36, 9(2009), pp. 1391-1402. https://doi.org/10.1139/L09-075

\section{Authors' addresses}

Dražen Cvitanić, Professor

Department of Transportation,

Faculty of Civil Engineering, Architecture and Geodesy,

University of Split

Matice hrvatske 15, 21000 Split, Croatia

E-mail: drazen.cvitanic@gradst.hr

\section{Biljana Maljković, Ph.D. student}

Department of Transportation,

Faculty of Civil Engineering, Architecture and Geodesy, University of Split

Matice hrvatske 15, 21000 Split, Croatia

E-mail: biljana.maljkovic@gradst.hr 